\title{
Peranan Wanita Dalam Persembahan Ritual Pengubatan Tradisional Magbuaya
}

\author{
Patta Ariffin Husin ${ }^{1}$, Sharifuddin Zainal ${ }^{2}$, Sim Chea Cheang ${ }^{3}$ \\ 1.2.3Fakulti Sains Sosial dan Kemanusiaan, Universiti Malaysia Sabah \\ e-mail: ${ }^{1}$ pattaariffinhusin@gmail.com, ${ }^{2}$ shah.zainal82@gmail.com, ${ }^{3}$ susansimcc@ yahoo.com
}

Diterbitkan dalam talian: 30 Jun 2020

Cite this article (APA): Husin, P. A., Zainal, S. \& Cheang, S. C. (2020). Peranan wanita dalam persembahan ritual pengubatan tradisional magbuaya. Jurai Sembah 1(1), 46-51. https://doi.org/10.37134/juraisembah.vol1.1.5.2020

\begin{abstract}
Abstrak
Etnik Bajau yang menduduki Kampung Seloka Empat, Pulau Bum-Bum, Semporna masih mengekalkan dan mengamalkan adat istiadat tradisional amalan nenek moyang yang berpaksikan kepada amalan ritual pengubatan berbentuk tradisional. Amalan nenek moyang yang diamalkan sehingga kini menerapkan nilai-nilai penghormatan kepada kaum wanita kerana mereka dianggap sebagai satu identiti gender yang berwibawa dan suci. Permasalahan kajian yang didapati adalah berkaitan dengan peranan penting kaum wanita dalam persembahan ritual pengubatan tradisional seperti ritual pengubatan magbuaya. Selain itu, wanita memainkan peranan yang sangat penting dalam pelaksanaan persembahan ritual pengubatan tersebut. Ini disebabkan, persembahan ritual pengubatan tradisional magbuaya ini penting bagi wanita untuk menjadi tumpuan dalam keseluruhan proses pelaksanaan serta kelancaran persembahan ritual pengubatan tradisional magbuaya ini. Hal ini kerana, waris kalamat (bomoh) adalah seorang wanita yang akan meneruskan persembahan ritual pengubatan tradisional magbuaya ini. Selain itu, para pembantu utama kalamat adalah wanita dan para pembantu atau dikenali sebagai dayang ini akan dibantu oleh para wanita terpilih yang terdiri daripada ibu tunggal, janda atau balu sahaja. Selain itu, kertas kerja ini mengaplikasikan kaedah kajian etnografi bagi mendapatkan data yang lebih kukuh. Salah satu syarat yang paling penting dalam persembahan ritual pengubatan tradisional magbuaya adalah peranan tujuh orang wanita yang masih dara sebagai dayang-dayang. Dapatan kajian menemukan bahawa wanita sangat memainkan peranan penting dalam ritual pengubatan magbuaya kerana kemenjadian sesuatu proses pengubatan adalah ditentukan oleh kewujudan peranan wanita.
\end{abstract}

Kata kunci: Bajau, dayang-dayang, kalamat, magbuaya, ritual pengubatan

\begin{abstract}
The Bajau people who reside in Kampung Seloka Empat, Bum-Bum island, Semporna still adhere to their ancestors' ways of performing traditional healing rituals. The ways of their ancestors that are still in use till these days are steep with maternal respect as women are regarded as a gender of honour and purity. The research problem that can be found is on the important roles of women in the traditional medicine ritual such as the performance of magbuaya medicine ritual. Other than that, women play important roles in performing the said medicine ritual. This is because the magbuaya traditional medicine ritual performance is important for the women to become the attraction in the overall process of the performance as well as the smooth going of the performance medicine ritual. The reason is that the kalamat inheritor is a woman that will continue the performance of the traditional magbuaya medicine ritual. Apart from that, the main assistants of the kalamat are women and the helpers or called 'dayang' will be assisted by women chosen from single mothers, divorcees and widows only. Other than that, this paper applies ethnographical study to get a more solid data. Furthermore, one of the most important rules in the magbuaya ritual is that the seven virgin women, will become dayang for three days until the end of the said ritual. The women hace their crucial duties to expedite the process of the performance in Kampung Seloka, Bum-Bum island. As a result, women really do play a vital role in performing magbuaya. Without women, the ritual will never be completed because they are the main pillars behind the traditional performance.
\end{abstract}




\section{Pengenalan}

Wanita mempunyai peranan yang penting dalam setiap sudut proses persembahan ritual pengubatan tradisional magbuaya yang masih dilakukan oleh etnik Bajau yang mendiami Kampung Seloka Empat, Pulau Bum-Bum Semporna. Gender wanita ini menjadi kod wajib dalam persembahan ritual pengubatan tradisional magbuaya kerana wanita yang terlibat mempunyai peranan dalam setiap bahagian sekaligus dapat melancarkan proses persembahan ritual.

Persembahan ritual pengubatan tradisional magbuaya membawa maksud "Berbuaya." Dalam persembahan ritual pengubatan tradisional magbuaya ini akan melakukan satu upacara seruan semangat pendamping iaitu semangat buaya betina putih (ombo' buaya pote') yang dipercayai sebagai semangat pendamping kepada kalamat (bomoh). Merujuk kepada Pisali (2017) mendefinisikan kalamat sebagai ketua dalam sesuatu persembahan ritual pengubatan tradisional atau lebih dikenali sebagai bomoh ataupun pawang. Persembahan ritual pengubatan tradisional magbuaya akan dilakukan selama tiga hari utama untuk upacara pengubatan sahaja, tetapi terdapat beberapa hari penting yang terdapat dalam sebelum melakukan persembahan ritual pengubatan tradisional magbuaya ini, antara hari penting tersebut ialah; (1) hari berakad, (2) hari mencari prop, dan (3) hari upacara persembahan ritual pengubatan tradisional magbuaya. Wanita memainkan peranan penting sepanjang berlangsungnya proses pengubatan bermula dari hari berakad sehinggalah selesai persembahan.

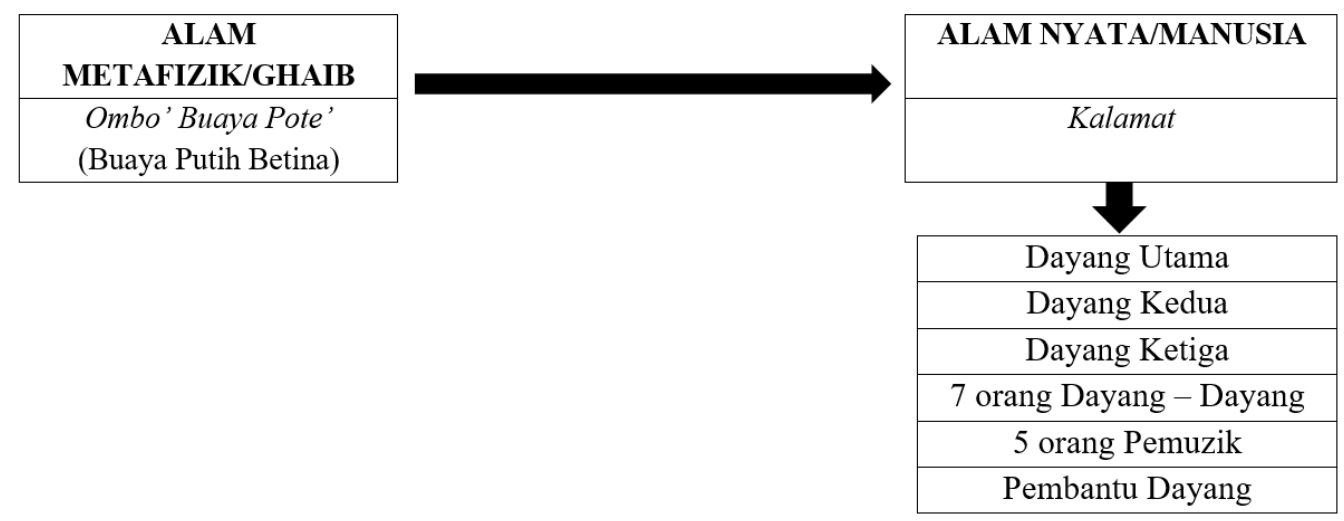

Rajah 1: Alam metafizik dan alam manusia

Rajah 1 menunjukkan alam metafizik yang merujuk kepada ombo' buaya pote', iaitu suatu identiti buaya betina. Sementara itu, alam nyata merujuk kepada alam manusia yang mana kalamat menduduki tempat teratas dalam hierarki persembahan ritual pengubatan tradisional magbuaya. Hierarki yang mengikuti kemudiannya adalah dayang utama, dayang kedua, dayang ketiga, dayang-dayang, pemuzik dan pembantu dayang. Hierarki tersebut menunjukkan bahawa kedudukan kalamat di tempat teratas menjelaskan bahawa identitinya adalah sangat suci dalam kepercayaan etnik Bajau. Justeru, pemilihan kalamat adalah wanita yang juga merupakan keturunan kalamat. Walau bagaimanapun, terdapat juga kalamat daripada kalangan lelaki yang mewarisi peranan tersebut daripada keturunannya. Hal ini berlaku ekoran seseorang kalamat itu tidak mempunyai waris wanita. Hal ini dibolehkan, akan tetapi lelaki tersebut haruslah mempunyai sifat-sifat seperti seorang wanita iaitu sensitif, lemah lembut dan feminin (Abduhu @ Rahim, N., personal communication, Jun 8, 2017).

Merujuk kepada OH (2016), di negara Korea mempunyai shaman (bomoh) yang memfokuskan kepada ritual tradisional dan kebanyakkan shaman tersebut merupakan seorang wanita. Hal ini mempunyai persamaan berhubung dengan kalamat yang mengemudi persembahan ritual pengubatan tradisional magbuaya ini adalah seorang wanita. Selain daripada itu, Pisali (2017) menjelaskan perkara yang sama berhubung dengan pewarisan untuk menjadi kalamat adalah melalui mimpi dan beberapa perkara lain. Sehubungan dengan itu, terdapat sembilan kalamat yang menjadi ketua dalam beberapa persembahan ritual pengubatan tradisional ataupun persembahan ritual tradisonal yang lain. Tambahnya lagi, terdapat beberapa kalamat wanita iaitu ombo' Rumihah dan ombo' Asiah yang masih mengekalkan dan mengamalkan persembahan ritual tradisional. 
Aranyosi (2010) The Russian Academy of Science, terdapat individu yang telah diramalkan menjadi seorang shaman dan individu tersebut terpaksa menolak disebabkan oleh beberapa perkara yang perlu difokuskan kepada masa depan. Oleh itu, individu tersebut terpaksa melalui beberapa fasa ritual untuk menolak kejadiannya untuk menjadi shaman agar individu tersebut tidak terkena sebarang malapetaka.

Dayang utama, iaitu pembantu kepada kalamat berperanan sebagai orang tengah kepada kalamat dalam menyampaikan atau menterjemahkan sebarang bentuk maklumat yang disampaikan oleh kalamat kepada semangat buaya putih (ombo' buaya pote') dan sebaliknya. Dayang utama akan mengalami trance, iaitu dirasuki oleh semangat buaya putih betina (ombo' buaya pote') ketika berkomunikasi dengan kalamat. Semasa dayang utama dirasuki oleh semangat tersebut, beliau akan bertindak seperti seekor buaya yang beraksi agresif dan ganas (Abduhu @ Rahim, N., personal communication, Jun 8, 2017). Tambahnya lagi, dayang utama akan melibaskan kakinya persis seperti seekor buaya yang melibaskan ekornya. Di samping itu, dayang utama yang telah dirasuki turut melakukan perkara yang di luar jangkaan, sebagai contoh beliau mampu memakan telur mentah dalam jumlah yang banyak.

Dayang kedua pula berperanan sebagai individu yang bertanggungjawab dalam penyediaan dan melengkapkan semua keperluan prop dan set yang digunakan dalam persembahan ritual magbuaya. Dayang kedua akan memulakan peranan beliau untuk mencari prop dan set ini setelah selesai hari berakad. Proses melengkapkan bahan ini mengambil masa yang sangat panjang kerana terdapat beberapa bahan yang agak sukar untuk dicari dan dipenuhi. Dayang ketiga pula berperanan sebagai individu yang bertanggungjawab dalam menyediakan bahan makanan dan masakan yang diperlukan dalam persembahan ritual magbuaya bermula daripada hari pertama sehingga selesai persembahan. Dayang utama, dayang kedua dan dayang ketiga merupakan anak-anak kepada kalamat yang akan menjadi pewaris utama setelah kewafatan kalamat.

Keberadaan tujuh orang dayang-dayang adalah bertindak sebagai pembantu kepada kalamat dalam persembahan magbuaya. Terdapat beberapa pantang larang dan syarat yang harus diikuti dalam pemilihan tujuh orang dayang-dayang tersebut seperti yang telah ditetapkan oleh kalamat. Sementara itu, para pemuzik juga terdiri daripada lima orang wanita yang berstatus sebagai ibu tunggal, janda atau balu. Selain itu, terdapat juga para wanita yang terlibat secara tidak langsung dalam melicinkan kelancaran persembahan ritual pengubatan magbuaya.

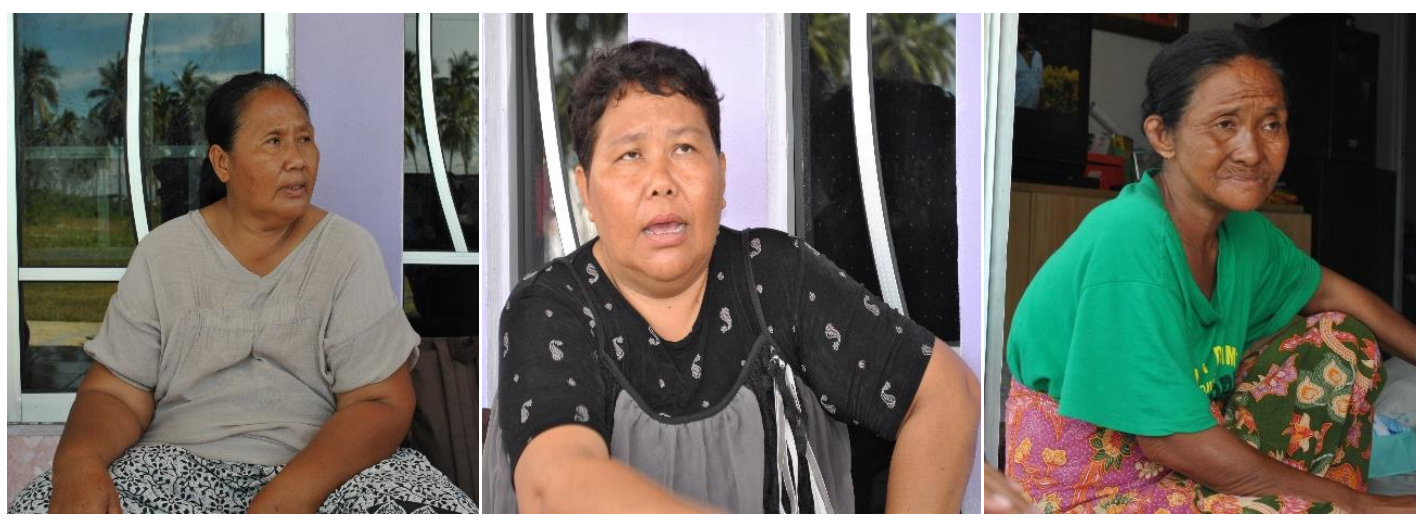

Rajah 2: Dayang-dayang (pembantu kalamat), iaitu dari kiri, Dayang Noreha, Dayang Nulsita dan Dayang Rosnah

\section{Peranan Wanita berdasarkan Turutan Hari dalam Persembahan Ritual Magbuaya}

Peranan wanita merupakan aspek yang mendapat perhatian serius untuk dibincangkan kerana terdapat pelbagai isu yang wujud. Terdapat beberapa kajian yang dilakukan oleh sarjana lepas seperti Hall (1990) dan Rostiyati (2017) yang menjelaskan bahawa konsep yang berkaitan dengan identiti adalah sesuatu konsep yang dimiliki oleh individu termasuklah wanita yang turut berhubungkait dengan pandangan orang sekeliling berkaitan dengan persamaan atau perbezaan yang terdapat dalam dirinya. Di samping itu, terdapat beberapa pendapat berkaitan dengan identiti seperti dalam kajian Buttler (1990) dan Abdullah et al. (2009) yang menjelaskan 
bahawa identiti itu terbentuk dengan cara wawancara dan secara performatif. Oleh yang demikian, identiti itu tidak terbentuk secara semulajadi dalam sesuatu masyarakat. Oleh yang demikian, peranan wanita serta identiti wanita dapat dilihat secara jelas dalam aliran persembahan ritual magbuaya.

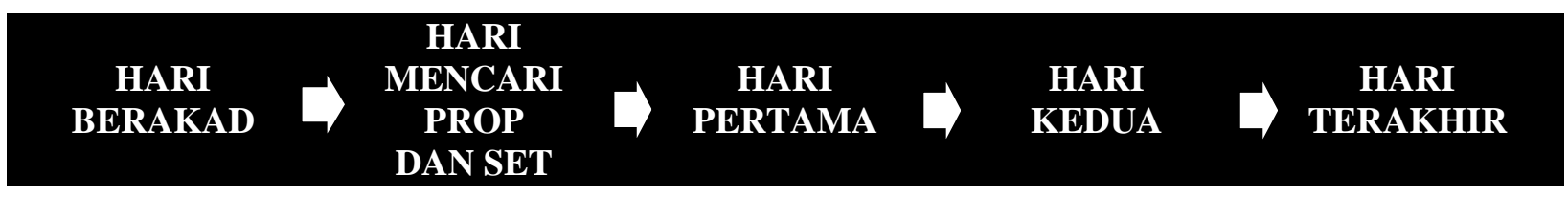

Rajah 3: Struktur persembahan ritual magbuaya

Merujuk Rajah 3, pada hari berakad kata sepakat harus dicapai di antara kalamat dan pesakit melalui perantaraan dayang-dayang yang menjelaskan kepada keluarga pesakit berkaitan syarat dan pantang larang yang perlu dipatuhi oleh keluarga pesakit. Dayang utama akan menerangkan semua perkara yang terdapat dalam persembahan ritual. Semasa proses berakad, kalamat akan menjelaskan kepada pesakit dan keluarga tentang pengeras (bayaran) yang perlu diberikan oleh pihak keluarga pesakit kepada kalamat. Pengeras tersebut akan digunakan untuk penyediaan kelengkapan sajian yang digunakan semasa persembahan ritual magbuaya.

Hari mencari prop dan set akan diketuai oleh dayang kedua dengan mencari dan membeli semua keperluan untuk persembahan yang berjumlah 24 bahan kesemuanya. Antara bahan-bahan prop dan set tersebut adalah seperti beras padi, budjak (lembing), tebu hutan dan pokok pisang liar yang merupakan syarat wajib untuk persembahan. Apabila semua bahan keperluan tersebut telah lengkap, dayang kedua akan menyusun semua prop dan set tersebut mengikut turutan yang telah ditetapkan. Selain itu, prop dan set lain yang wajib ada bagi melaksanakan persembahan ritual magbuaya adalah seperti yang terdapat dalam Jadual 1 berikut.

Jadual 1: Senarai prop dan set persembahan ritual pengubatan tradisional magbuaya

\begin{tabular}{|l|l|l|l|}
\hline Bil & \multicolumn{1}{|c|}{ Prop/Set } & Bil & \multicolumn{1}{c|}{ Prop/Set } \\
\hline 1 & Kain kuning & 13 & (2 kotak) lilin \\
\hline 2 & Mangkuk putih & 14 & (1 batang) lembing/budjak \\
\cline { 2 - 4 } & Beras kunyit Diikat bersama & 15 & (1 bilah) Parang \\
\hline 4 & Pulut putih & 16 & (3 batang) tebu hutan \\
\hline 5 & Pulut hitam & 17 & (1 bungkus) Kemenyan \\
\hline 6 & (3 sisir) Pisang raja & 18 & (1 batang) pokok pisang \\
\hline 7 & (1 ekor) Ayam kampung jantan & 19 & (4 kg) minyak kelapa \\
\hline 8 & Mayang pinang & 20 & (30 biji) pinggan \\
\hline 9 & (60 biji) Telur ayam & 21 & (7 orang) anak dara yang masih dara dan suci \\
\hline 10 & (1 helai) Kain pelikat/tadjung & 22 & (1) Perahu \\
\hline 11 & (80 saiz kecil) (60 saiz besar) & 23 & (1) Tembikar \\
\hline 12 & (1 botol) Minyak air mata duyung & 24 & (1) gulung tikar nipah \\
\hline
\end{tabular}

Pada hari pertama, beberapa individu yang akan terlibat antaranya ialah seorang kalamat, dayang utama, lima orang pemain muzik, tujuh dayang-dayang yang masih dara dan suci serta pesakit yang akan dirawat. Dayang utama bertanggungjawab sebagai pembantu kepada kalamat dengan bertindak sebagai perantara. Seterusnya, para pemuzik akan memainkan muzik berentak limbayan (tagunggu' titik limbayan) dan diikuti dengan igal limbayan yang ditarikan oleh tujuh dayang-dayang sebagai suatu proses penyucian diri untuk semua yang terlibat. Justeru, para tetamu yang datang tidak kira dengan niat untuk menonton atau ingin menziarah keluarga boleh turut serta menari igal limbayan bersama-sama. Namun begitu, sekiranya niat mereka tidak ikhlas maka individu yang menari tersebut akan dimasuki oleh semangat jin buaya yang diseru.

Dayang utama yang mengalamai trance akan berperwatakan seperti seekor buaya dengan menampilkan tindak-tanduk yang agresif dan ganas. Sewaktu inilah dayang utama bertindak sebagai perantara di antara kalamat dan semangat buaya putih betina melalui proses komunikasi. Kalamat akan bertanyakan pelbagai jenis soalan berkaitan dengan penyakit yag dialami oleh pesakit. Setelah proses komunikasi tersebut selesai, kalamat akan menerangkan kepada pihak pesakit tentang punca penyakit yang dialami. 
Sementara itu, tujuh dayang-dayang wanita yang masih dara dan suci terpilih kerana kejujuran dan kesucian mereka yang sangat memainkan peranan dalam kemenjadian proses pengubatan pesakit. Tujuh dayang-dayang bertindak sebagai pembantu dalam persembahan ritual magbuaya dengan sebagai penari yang igal limbayan mengikut titik limbayan yang dimainkan oleh para pemuzik. Selain itu juga, dayang-dayang turut ditugaskan untuk mengambil air dari rumah para penduduk Kampung Seloka Empat. Caranya adalah dengan 'mencuri' air tersebut dan sekiranya tuan rumah ataupun sesiapa sahaja yang menegur atau melihat kejadian 'mencuti' itu, individu tersebut haruslah disimbah dengan air yang 'dicuri' itu menjadi lupa tentang apa yang telah dilihatnya. Air yang 'dicuri' kemudiannya akan disimpan dalam tembikar batu.

Lima orang pemuzik wanita pula dipilih berdasarkan mandat daripada makhuk halus yang mengkhaskan mereka untuk memainkan muzik bagi persembahan ritual magbuaya yang diterima melalui mimpi. Dalam mimpi tersebut, mereka melaihat cahaya muncul sambil diiringi bunyi muzik tagunggu' titik limbayan. Antara alat muzik yang dimainkan adalah gong (agong), gendang (tambul) dan kulintangan. Para pemain muzik ini akan memulakan paluan titik limbayan bermula sejak dari selepas solat zuhur yang dimulai dengan paluan gong sebanyak tiga kali sebagai tanda permulaan persembahan ritual pengubatan magbuaya.

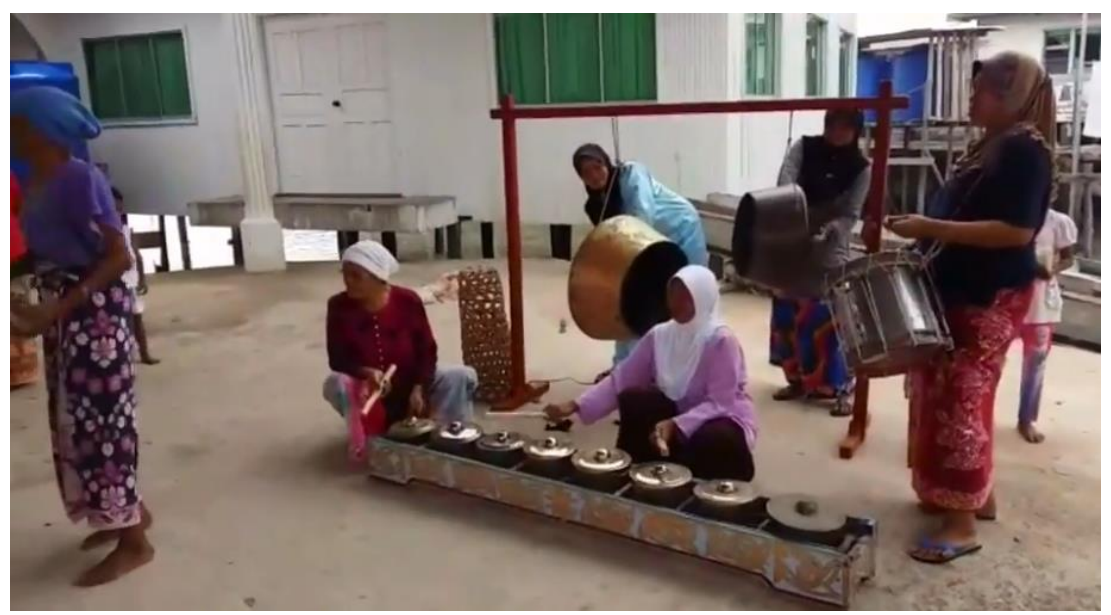

Rajah 4: Lima orang pemuzik yang terdiri dalam kalangan wanita.

Dayang ketiga pula berperanan dalam penyediaan sajian yang merupakan juadah yang disantap sepanjang persembahan ritual pengubatan magbuaya. Ritual khas yang dikendalaikan oleh dayang ketiga dikenali sebagai upacara magkanduli (kenduri). Dayang ketiga menyediakan sajian juadah dengan dibantu oleh para pembantu wanita yang terdiri daripada ibu tunggal, janda ataupun balu. Pada hari terakhir persembahan ritual magbuaya, sajian juadah yang disediakan perlu dimasak sendiri oleh dayang ketiga. Justeru, peranan wanita, iaitu kalamat, dayang utama, dayang-dayang, pemuzik dan dayang ketiga akan berlanjutan selama tiga hari berturut-turut sehingga tamatnya persembahan ritual pengubatan magbuaya. Pada hari pertama dan kedua tidak banyak perbezaan upacara yang dilakukan kerana upacara yang dilakukan merupakan pengulangan. Namun, pada hari ketiga terdapat sedikit penambahan upacara memandangkan ia merupakan hari terakhir persembuhan ritual pengubatan magbuaya.

Sehubungan dengan itu, peranan wanita dalam hal ini dilihat sebagai satu konsep pemerkasaan memandangkan wanita diberikan dominasi kuasa untuk melaksanakan persembahan ritual pengubatan magbuaya. Selain itu, peranan wanita juga dilihat sebagai suatu aspek kebebasan untuk menceburi bidang ekonomi, sosial dan kebudayaan yang sesuai dalam proses mengubah corak kehidupan. Di samping itu, merujuk Kabeer (2010) dan Mosedale (2005), pemerkasaan wanita juga adalah proses wanita mencipta sesuatu yang wanita boleh lakukan atau capai sesuatu yang sebelum ini tidak dapat diterima oleh sesuatu masyarakat berhubung dengan gender wanita. Menurut Kabeer (2010) dan Mosedale (2005), pemerkasaan wanita adalah satu proses di mana wanita akan meluaskan serta mencipta sesuatu yang wanita boleh lakukan dan boleh mencapai dalam keadaan yang sebelum ini tidak diterima atas diskriminasi terhadap seksualiti wanita. Tambahnya lagi, pemerkasaan wanita ini sebagai satu alternatif dalam proses pentakrifkan peranan jantina yang 
membolehkan mereka untuk membina kejayaan serta keupayaan tanpa ada batasan berkaitan dengan identiti gender. Selain itu, terdapat beberapa prinsip bagi menentukan pemerkasaan wanita antaranya ialah: (1) untuk seseorang diberi kuasa, (2) daripada golongan tidak berkuasa, (3) memperoleh kuasa sendiri dan (4) bukannya diberi oleh pihak luar. Sarjana lepas menjelaskan pemerkasaan sebagai melibatkan individu untuk membuat keputusan yang penting dalam kehidupan mereka. Akhirnya pemerkasaan dan ketidakupayaan adalah suatu yang berhubungkait terhadap sesuatu, pemerkasaan merupakan satu proses dan bukannya satu produk (Mosedale, 2005). Oleh yang demikian, persembahan ritual pengubatan magbuaya merupakan suatu proses pemerkasaan wanita seperti yang ditakrifkan oleh Kabeer (2010). Peranan wanita dalam persembahan ini penting kerana setiap proses perlaksanaannya didominasi oleh wanita.

\section{Kesimpulan}

Persembahan ritual pengubatan magbuaya menekankan dominasi wanita yang memainkan peranan penting dalam pelaksanaan persembahannya. Hal ini menegaskan bahawa wujudnya kuasa dominan wanita dalam menentukan kemenjadian suatu proses pengubatan. Ia merupakan simbolik penghargaan terhadap wanita khasnya melalui kepercayaan terhadap semangat ombo' buaya pute' yang menampilkan wanita sebagai ketua bomoh yang menjadi rujukan dalam kepercayaan tradisonal etnik Bajau.

\section{Rujukan}

Abdullah, I. , Udasmoro, W. \& Hasse, J. (2009). Dinamika masyarakat dan kebudayaan kontemporer. TICI Publications $\&$ Pustaka Pelajar.

Aranyosi, E. (2010). A Buryat Shaman woman and her rituals in the 21st Century [Doctoral dissertation, Eötvös Loránd University]. http://doktori.btk.elte.hu/lingv/aranyosieva/thesis.pdf

Butler, J. (1990). Gender trouble: Feminism and the subversion of identity. Routledge, Chapman \& Hall, Inc.

Hall, S. (1990). Cultural identity and diaspora. In Rutherford, J. (ed.), Identity: Community, culture and difference (pp.222237). Lawrence \& Wishart.

Kabeer, N. (2010). Gender equality and women empowerment: A critical analysis of the third millennium development goal. Gender \& Development, 13(1), 13-24. https://doi.org/10.1080/13552070512331332273

Mosedale, S. (2005). Assessing women's empowerment: Towards a conceptual framework. Journal of International Development, 17(2), 243-257. https://doi.org/10.1002/jid.1212

OH, K.- geun. (2016). Korean shamanism - The religion of women. International Journal of Korean Humanities and Social Sciences, 2, 71-86. https://doi.org/10.14746/kr.2016.02.05

Pisali, A. (2017). Fungsi dan struktur persembahan tari ritual Panansang di daerah Semporna Sabah [Master's Dissertation, Universiti Malaysia Sabah]

Rostiyati, A. (2017). The role of women in traditional ceremony of Rahengan in Citatah Village, West Bandung Regency. Patanjala: Jurnal Penelitian Sejarah dan Budaya, 9(3), 359-374. 